\section{ECONOMICS}

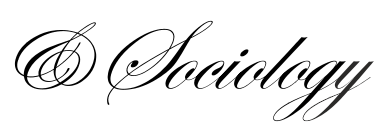

Udzhmadzhuridze, H., Bilan, S., \& Kryvoshein, V. (2019). Individual significance of political participation in today's Ukrainian society: The case of Dnipro city. Economics and Sociology, 12(1), 193-207. doi:10.14254/2071-789X.2019/12-1/11

\title{
INDIVIDUAL SIGNIFICANCE OF POLITICAL PARTICIPATION IN TODAY'S UKRAINIAN SOCIETY: THE CASE OF DNIPRO CITY
}

\author{
Heorhii Udzhmadzhuridze, \\ Department of Sociology, \\ Oles Honchar Dnipro National \\ University, \\ Ukraine \\ E-mail: \\ g.udzhmadzhuridze@gmail.com
}

Svitlana Bilan,

Faculty of Management,

Rzeszón University of Technology,

Poland

E-mail:s.bilan@prz.edu.pl

\author{
Vitaliy Kryvoshein, \\ Department of Sociology, \\ Oles Honchar Dnipro National \\ University, \\ Ukeraine \\ E-mail:1-704@i.ua \\ ORCID:0000-0002-3380-7850
}

Received: October, 2018

1st Revision: December, 2018

Accepted: February, 2019

DOI: $10.14254 / 2071-$

789X.2019/12-1/11

JEL Classification: D72

\begin{abstract}
The article is dedicated to consideration of the phenomenon of political participation and its individual functional significance in the context of contemporary Ukrainian society. Several theoretical approaches to analysis of the phenomenon of political participation are presented. Exploration of the phenomenon of political participation in the context of Ukrainian society is carried out through the use of methodological ideas of the social practice theory. Through the analysis of qualitative semi-structured interviews of political activists of the Dnipro region, the functional sense and individual significance of political participation are clarified. The author draws the conclusion that in the region in question political participation of individuals: actualises the deep sociocultural divisions, serves as an instrument of struggle between citizens and political elites for the establishment of civil society, enhances social cognitions stereotyping, construct the space of sociopolitical identities.
\end{abstract}


Ukraine, as a transformational society, with its development path towards the democratization of social life, this issue has become extremely relevant in recent years (Wawrzonek, 2014).

The "Revolution of Dignity" and the events that accompanied it gave a new push to the development of civil society, but at the same time they became the reason for the emergence of new forms of political participation of individuals within Ukrainian society (Siryi, 2016; Smyth, 2018). Thus, the events of recent years have actualised the researches of the Ukrainian context of political participation of individuals (Aasland \& Lyska, 2016). The attention of Ukrainian scientists is focused on the methodology of political participation measuring (Savelyev, 2016), on the factors raising political participation level (Reznik, 2016), on the linkage between political culture and political participation (Marchenko, 2016), on the typologies of political participation forms (Kliuienko, 2005), on the problems of political apathy and electoral fraud of citizens (Makarenko, 2014), on the weak influence of political participation on the political elite (Bortnykov, 2007). However, there are no explorations into the sense of political participation at the individual level, therefore, there is no knowledge about individual significance of political participation. Thus, we will concentrate our attention on this particular issue.

Thus, the purpose of this article is to explore the individual significance of political participation in today's Ukrainian society. To realize this purpose we will: present the theoretical approaches to definition of the sense of political participation of individuals, substantiate the application of the methodological positions of the theory of social practices to the analysis of the phenomenon of political participation of individuals, offer the author's position concerning the phenomenon of political participation of individuals, analyse the collected data from qualitative semi-structured interviews of the political activists in the Dnipro city and draw the conclusions from our research. The article consists of three sections, conclusions, the list of references and appendices.

\section{Theoretical approaches to the definition of the sense of political participation of individuals}

Studies of the phenomenon of political participation are carried out in the contextual field of several sciences, among them: sociology, political science, psychology, economics and political economy, philosophy. We can distinguish (generalize) several approaches to the interpretation of the sense of political participation of individuals:

\subsection{System-institutional approach to the analysis of political participation of individuals}

In this approach, political participation is treated as an attribute of the political system, endowed with institutional functions to stabilize the entire social system.

Under the political participation, T. Parsons understands the attribute of power of groups and their members over the state and its organs. In modern social systems, the relationship between the political sphere (in the form of government) and the societal community (in the form of collective voluntary associations) takes place through "the support" of: public leaders and initiatives on the one hand and government decisions and needs in support among the population on the other. An evolutionary differentiation of the state and society takes place: society gets the opportunity to exercise power influence over the government through the institutions of political participation (Parsons, 1971).

Political participation of individuals is analysed by G. Almondm in the context of considering the process of a political course adoption in the political system. Political participation takes place during the process of articulation of the interests of individuals and social groups. In complex political systems political participation gives the opportunities to 
the individuals and groups to express their demands about local (everyday) issues and national policies, strategies, and standards(Almond, Powell Jr., Dalton, \& Strom, 2007).

S. Huntington sees in political participation the constant process of expressing social claims to political institutions by social groups. A modern person believes in his ability to change the world, has sufficient competences for political participation. In modern conditions the nation is the primary subject of sovereignty, the political elite is perceived as the legitimate representative of the delegated power (Huntington, 2006).

R. Putnam sees political participation as a clear indicator for the definition of the "citizenship" of an individual or community. Citizenship is characterized by: civic engagement, political equality, solidarity, trust and tolerance, the presence of voluntary associations. The regular political participation of individuals promotes the spreading of norms of citizenship (Putnam, Leonardi, \& Nanetti, 1994).

\subsection{Conflict approach to the analysis of political participation of individuals}

In this approach, political participation is interpreted as a process of expressing social groups' (classes, communities, unions, movements) demands to a political system represented by the political elite, bureaucracy and institutions.

S. Lipset sees the political participation of the population as a condition that increase the stability of democracy. Due to political participation creates a social associations that are able to integrate into a political life and enter a conventional conflict with the political authorities. Poverty, the lack of communication networks, blocking the opportunities of political participation of certain social groups lead to ideologization and extremization of the population - in such conditions, a stable functioning of the democratic political system is impossible (Lipset, 1985).

R. Dahrendorf under the subjects of political participation sees the social groups who struggle for their rights and economic preferences. The access of individuals to the political participation is the main goal of political development, its provision is associated with the increasing of chances of choosing real alternatives (political freedom). Political freedom realization is impossible without civil society: the civil society acts as an intermediary between the state and society as a sum of social structures. The social conflicts of the modern age are connected with the full inclusion of social groups in civil society (Dahrendorf, 2007).

\subsection{Cultural-value approach to the analysis of political participation of individuals}

In this approach the political participation is interpreted as a manifestation of cultural and value patterns of individuals' behaviour.

S. Verba and G. Almond describe political participation of individuals as a key feature of civil political culture. Investigating cases of the political participation of citizens, the authors conclude that individuals tend to cooperate with "close to themselves" to achieve their goals at the local level and with formal groups at the national level. Individuals with high political competence feel the political participation as a psychological need, such individuals understand the importance and necessity of political participation to support a democratic regime of government (Almond \& Verba, 2015).

$\mathrm{R}$. Inglehart and $\mathrm{C}$. Welzel analyse the political participation in the context of reviewing the process of modernization. The modernization inevitably changes the values from collective to individual. Increasing of individual self-expression, as value, produces an expansion of civil and political rights. The emancipative nature of post-materialism values of self-expression weakens the authority of political elites and enhances the role of participation in political life. In the post-industrial age, the traditional institutional forms of political 
participation are inferior to more expressive, spontaneous and protest forms (Inglehart \& Welzel, 2005).

\subsection{Communicative-interactive approach to the analysis of political participation of individuals}

In this approach, political participation is seen as some type of deliberate practical activity for transforming the surrounding social world.

M. Olson analyses the role and functions of political participation in the context of approbation of the theory of state formation. The prominent role of small social groups characterizes the political participation process. The interdependence of the members of a small social group forces each member of this group to act in such way that it will benefit both him and the whole group. Thus, political participation in society is expressed by the possibility of the struggle of social groups for political power (Olson, 1993).

A. Giddens pays attention to the political participation of individuals in the studies of the global process of democratization. The foundations of democracy are political (right to political participation) and civil (right to free membership in voluntary associations) rights (Giddens, 2011). Citizens of developed societies prefer direct forms of political interaction political participation through voluntary associations. In modern societies, the social movements are the most effective means of citizens interests realization through the political sphere. Social movements combine the interests of several voluntary associations and can bring a significant political and social changes in society (Giddens, 2009).

J. Habermas studies the phenomenon of political participation in the context of the genesis of formation of nation-states of modern Europe. The national self-identification transformed the subjects into politically active citizens through the creation of solidarity identity. Only in the context of national solidarity political participation have a real power - a mass support from the people and compulsory reaction from the political authorities. The political participation itself Habermas treats as a spontaneous consent of the volitional manifestations of the representatives of one nation (Habermas, 2000).

\section{Methodological strategy for the research of the phenomenon of political participation of individuals in the modern Ukrainian society}

Being based on the problem situation of our exploration and the results of studying the development of theoretical approaches to the definition of the phenomenon of political participation we consider the use of the methodological positions of the theory of social practices to be the most heuristic-based and relational ones to the purpose of our study.

The theory of social practices is part of the complex of "synthetic" (dual) methodological approaches. This methodological optics allows to study the individual (microlevel) significance of political participation, as well as the systematic (macro-level) characteristics of this experience. In addition, this approach makes a great emphasis on the contextuality of the practice' reproduction environment. Therefore, it is capable to reflect adequately the nature of Ukrainian society as a transformational one.

In our study, we tend to use the explications of the "French school" of the theory of practice, which is represented by the works of P. Bourdieu, M. de Certeau, L. Boltanski and L. Thevenot. Our choice is due to:

- Firstly, the political participation is realized in the political sphere of society;

- Secondly, Ukrainian society is characterized by sociocultural differences (divisions) which effects on political sphere of society; 
- Thirdly, the positions of the "French school" allow us to fixate the internalized schemes of identification (classification) of individuals on "We-They-Others".

The practices by $\mathrm{P}$. Bourdieu are objectified and incorporated products of practical history, social structures and habitussen. The system of stable dispositions, which are already structured by past practices, but also structuring the future practices, is called "habitus". Habitus is produced by social structures that transmit the accumulated experience in the form of dispositions through the system of pedagogical education. Habitus does not determine the practice, it only sets certain limits beyond which practices can neither be realized nor perceived. Within these limits the agent can choose the form and direction of practice that is most effective for him in implementing a strategy to consolidate his position in a certain field of society. Every practice is a personified action and, at the same time, a group (collective). It is possible because the practices of the representatives of the one group (community, class) are well-coordinated among themselves due to the similarity of the habitus of the group' members (Bourdieu, 1998). Political participation of individuals can be considered as an objectively determined social practice, which aimed to satisfy certain (sub)conscious needs and goals (which are not necessarily lying in the political sphere) through influence on the political field of society.

The Society according to $M$. de Certeau consists of institutionalized and noninstitutionalized social practices. Practice consists of procedures, when the practice becomes domineering (included in the authoritative discourse of imposing of social order) - procedures are institutionalized. Schemes of practice reproduction ("rules of the game") are fixed in folk culture in the form of fairy tales, myths and wisdoms. Human from small age is taught to abide the rules (strategies) of existing social order through children's games. However, in every folk story, for each social group, there is an example of the struggle against the injustice of the existing social order, the oppressed status of human. The strategy of science is to comprehend the practice by applying to its research a limited in its capabilities discursive description procedures and mathematical prediction procedures. While studying the practice, the main problem of a scientist is to fix the whole context of situations (which greatly effects on practice). The most effective tool for a scientist is the interview with the participants of practice - it can help to identify the causes, tools and products (results) of practice. The statistical methods play a descriptive role: they are able to distinguish the types of behavioural acts and calculate their number (Certeau, 2011). Political participation can thus be considered as a social practice that has both institutionalized (conventional) and non-institutionalized (unconventional) procedures and plays its own role in supporting social life

L. Boltanski and L. Thevenot say that the main factor of determining the scheme of implementation of practice is related to the feeling of what is justly in each particular situation. The participant selectively defines a justly, in his opinion, scheme of action and embodies it in everyday practices. The authors distinguish the seven ${ }^{1}$ "orders of worth" - the ideal systems of values and dispositives. Each of the orders in the practical reality is represented by the domains. In each practice there is a combination of principles of several orders simultaneously. Thanks to the feeling of what is justly (order) a person is able to classify the others. On the basis of classifications, a space of identities is created in a society. People with same identities are united into groups and communities that are trying to enhance the dignity of their order and to spread the sense of necessary justice on the others. In the study of practice, both the context of the situation and the justification of the individual are important. The tasks of the scientist are to distinguish the models of used orders and trace the interpreted context of the situation through the interviews (Boltanski \& Thevenot, 2006).

\footnotetext{
${ }^{1} 6$ forms (inspired, domestic, fame, civic, market, industrial) were given in Boltanski \& Thevenot (2006) and 1 form (projective) was given in Boltanski \& Chiapello (2007).
} 
Political participation, therefore, can be seen as a practice of the civic domain. The specificity of each form depends on combination of one civic order with another.

After analysing the theoretical approaches to the definition of the sense of political participation and choosing our methodological position, we can offer our own definition. Political participation is a social practice to satisfying and protecting (sub)conscious interests of individuals through changes of social order by influencing the political field of society. The form of realization of political participation practice depends on a set of value orientations of the individual and contexts of the situation - the chances of successful implementation of political participation.

\section{Conducting an empirical research and analysing the results}

To analyse the phenomenon of political participation from the methodological positions of the theory of practice, in the period from 18.05.2018 to 08.06.2018 we conducted a number of qualitative semi-structured interviews with inhabitants of the Dnipro city. The tools of the used guide (questionnaire) is given in Appendix 1.

Dnipro city is the regional centre of the Dnipropetrovsk oblast. Dnipropetrovsk oblast is the second largest one by territory and the second one by population in Ukraine (Chyseljnistj naselennja, 2018). Due to the high level of development of industry, technologies and the agrarian sector, the region has one of the highest level of population income among other regions of Ukraine (Dokhody naselennja po reghionakh Ukrajiny, 2017). The region, like the whole of Ukraine, shares a number of sociocultural divisions: $79.3 \%$ of the region' population consider themselves as Ukrainians, $17.6 \%$ as Russians, $0.8 \%$ as Byelorussians, $0.4 \%$ as Jews, $0.3 \%$ as Armenians and $0.2 \%$ as Azerbaijanis; $67 \%$ of the region' population consider Ukrainian as their native language, $31.9 \%$ - the Russian language (Nacionaljnyj sklad naselennja Ukrajiny, 2001). The Orthodox Christians call themselves $83 \%$ of the regional population: $33 \%$ of them consider themselves to the Ukrainian Orthodox Church of the Kyivan Patriarchate, 14\% - to the Ukrainian Orthodox Church of Moscow Patriarchate and 51\% call themselves "just Orthodox" (Relighijni vpodobannja naselennja Ukrajiny, 2015). If we construct a "Cultural map" of values according to the methodology of R. Inglehart and C. Welzel (Diez-Medrano, n.d.), then Dnipropetrovsk region will be located along with other major and most developed regions of Ukraine (Appendix 2).

Dnipro city is the fourth largest city of Ukraine (Chyseljnistj najavnogho naselennja Ukrajiny, 2018) and it also characterized by a number of sociocultural divisions. Thus, as Ukrainians consider themselves $72.6 \%$ of the region' population, $23.5 \%$ as Russians, $1 \%$ as Jews and $1 \%$ as Belarusians (Nacionaljnyj sklad naselennja Ukrajiny, 2001). The Ukrainian language is used daily by $19 \%$ of the regional population, the Russian language $-45 \%$ and either both languages - 36\% (Otnoshenye zhytelej Dnepropetrovskoj oblasty, 2015). Generally, such divisions influence both ideological and electoral orientations of the population, especially during the periods of social-political destabilization (Torikai, 2018).

As the informants of our research we have chosen the inhabitants of the Dnipro city, who are distinguished by high political activity in various protest actions or civil activities, have influential accounts on the Facebook (over 2000 subscribers/friends), presented in the discourse of local media as "local political expert" or "activist".

As a method of sampling was chosen a "snowball". At the first stage 3 informants were selected; at the end of the interview, each informant was asked for contact a person who would fit under such an interview. All interviews was conducted in public places (cafes, parks) with the recording of the materials of interviews on digital voice recorder. The average interview time was approximately 40 minutes. 
The final sample is 10 informants, the interviewing of new informants was stopped because of empirical and theoretical information repetition the final percentage of refusals from interview is $37,5 \%$. It should be noted, that according to the results of the Ukrainian survey "KIIS Omnibus" for December 2016: 2,9\% of Ukrainians is ready to participate the boycotts, $2,4 \%$ is ready to participate the Illegal meetings and demonstrations, $3,4 \%$ is ready to participate the strikes, $2,3 \%$ of population is ready to participate the picketing of governmental offices (Opinions and views of Ukrainian people, 2016). Based on this, we can consider the political activists as the small social group with the large number of common social characteristics (habitus, feeling of justly, values etc.); therefore, the variety of these characteristics in other regions of Ukraine should not be significant. Informants in our research vary in gender, age, education, income, and the field of their political activity (political participation). The characteristics of informants are given in Table 1.

Table 1. Characteristics of informants

\begin{tabular}{ccccccc}
\hline Code & Name & Age & $\begin{array}{c}\text { Educational } \\
\text { level }\end{array}$ & $\begin{array}{c}\text { Sphere of } \\
\text { earnings }\end{array}$ & $\begin{array}{c}\text { Language } \\
\text { of interview }\end{array}$ & Political activity \\
\hline I1 & Vadym & 47 & Higher & Businessman & Russian & $\begin{array}{l}\text { Party activist, deputy of city } \\
\text { council }\end{array}$ \\
\hline I2 & Dmytro & 24 & Higher & Project manager & Ukrainian & Civic activist \\
\hline I3 & Maksym & 30 & Middle & Freelancer & Russian & $\begin{array}{l}\text { Euromaidan participant, leader } \\
\text { of the protest movement }\end{array}$ \\
\hline I4 & Olha & 26 & Higher & Wage labour & Russian & $\begin{array}{l}\text { Euromaidan participant, leader } \\
\text { of the protest movement, civil } \\
\text { right activist }\end{array}$ \\
\hline I5 & Olha & 21 & $\begin{array}{c}\text { Incomplete } \\
\text { Higher }\end{array}$ & Student & Russian & Youth activist \\
\hline I6 & Maksym & 27 & Higher & Journalist & Russian & Leader of the youth movement \\
\hline I7 & Olena & 50 & Higher & TV program host & Ukrainian & Political observer, thought leader \\
\hline I8 & Olha & 30 & Higher & Wage labour & Ukrainian & $\begin{array}{l}\text { Gender activist, Euromaidan } \\
\text { participant, leader of the social } \\
\text { movement, human rights activist }\end{array}$ \\
\hline I9 & Liudmyla & 61 & $\begin{array}{c}\text { Academic } \\
\text { degree }\end{array}$ & Pensioner & Ukrainian & $\begin{array}{l}\text { Thought leader, Euromaidan } \\
\text { participant, leader of the social } \\
\text { movement }\end{array}$ \\
\hline I10 & Anzhelika & 48 & Academic & Project manager & Russian & $\begin{array}{l}\text { The head of a civic organization, } \\
\text { a deputy of the city council }\end{array}$ \\
\hline
\end{tabular}

Source: own data

During the research it was established that citizens tend not to call the political events in which they take part "political", they prefer to use the name "civic": "No, not political. I am engaged in civic activity and represent a civil society" (I9). "Political" actions are associated with the activities of the authorities, their representatives or with professional political career: "Well, because I'm not... I'm not striving for power, not running for the local authorities, so now I'm civic" (I6). Therefore, self-title of this group is "civic activists". In general, the experience of political participation (both successful and not successful) automates the reproduction of political participation: "And now it's all (clicking the fingers) faster and easier. You thought - yes, everything is good - you get up and do and do not think about whether you need it or not" (I1).

Depending on the difference in the degree of organization of the action of political participation, the combination of the logic of orders also differs. For a more spontaneous, unexpected participation, the combination of civic and inspired orders is typical: "You see, we were united at one time by one goal - to make life in the state better. Probably, it united us, 
and really many people think similar to me" (I3); "I am inspired by people, many people with whom I communicate, and especially in 2014, when these events happened and the Heavenly Hundred perished at Maidan, the defence of Ukraine in the Ukrainian-Russian war, when I saw a lot of responsible citizens in Dnipropetrovsk region - it inspires" (I9). Instead, the prepared and planned participation is characterized by the combination of the civic and projective orders:" As the coordinator of Euromaidan in Dnepropetrovsk I was addressed by organization that asked, offered its assistance in the protests' organization. And we somehow became friends, held joint actions in terms that they had a cars' resource, I had a resource of people, I owned the information" (I4). A fame order is also close to the projective order - on the basis of communication with verified persons, political participation is intensified: "Also, this can be due to the communicative nature of a person who convinces others that he is capable of achieving his goal and others will help him" (I2); "If my friend I. Ch. needs my presence at an ecological event - she writes to me and if I am in Dnipro, I write - "Yes". I see that with civic responsibility there are more opportunities for partnership projects, actions" (I8).

At the level of local political power, the fact of existence of a number of restrictions to the political participation of citizens has been established. The initiatives of individuals and civic organizations are filtered and selected, being based on the usefulness of the initiative to the authorities and "comfort" of the initiators: "They can help, but this should be in their real interest. That is, if they help with the project, it should, somehow, have a positive effect on their image or attract some influential people to their side, who used to be neutral to this authority body before» (I2). There is no circulation of local elites through political participation, the existing rules of "the game" in power structures rigidly specify the necessary behaviour of the individual: "I know a lot of activists who went there after 2014, but nobody survives there, practically. And if survives, they are either opportunists, or people who can lobby someone's interests, or they can be like snakes" (I3). In addition, there is an expression of destructive social capital (in the form of a combination of principles of domestic and fame orders), expressed in the preferences provision by the authorities only to "theirs": "In my experience - it's impossible. If you are a person from the outside you will never get anything, only personal. Only, if this is not quite an awesome decision that coincides with their "ideas" (I6).

It was noticed that political participation has signs of socio-psychological need political participation is a kind of social impulse aimed at improving living conditions: "That is understandable, when the following events took place, I have been waiting for the Maidan since 2010 - will people come out? Will it be? - And when the first moments began, when he refused to sign the Association with the European Union..., I think I would in any case participate. Because what the hack will some person decide my fate and the fate of my children?" (I4). If the opportunities for political participation are blocked, individuals satisfy this need through civic participation: "That what is happening after the Revolution of Dignity - I am watching the changes that happen. Some of the representatives of authorities act at the level of those stereotypes of imperious thinking, the patterns of that they capture from the previous regime. But now we are forming a powerful civil society that shifts the emphasis in these dialogues between authorities and civil society. Not everyone in the authority likes this, let's say so" (I9). Blocking the initiatives of citizens at the level of civic participation, activates the unconventional type of political participation: "(Illegal mechanisms) are applicable in extreme situations, when there is no dialogue, the dialogue immediately appears" (I10).

So, political participation is being implemented through civic organizations and may defined as civic participation. Civic participation is being implemented through civic organizations that are the structures of civil society. The inability of individuals to move from 
the civic participation to the political one might lead to destabilization of the political system and devolution of the civil society: "Look, if we do not cooperate with the state's bodies, what kind of sustainability of society we can talk about. This will be some kind of asceticism of civil society. Because, frankly, I do not really like many people in present power. But I work with representatives of the Verkhovna Rada, the Cabinet of Ministers and the Patrol Police» (I8).

In addition, the inequality of rights between civic organizations and citizens promotes the civic participation. The laws of Ukraine infuse the privileges for "game" in the political space of society (field) to civic associations (institutionalized and legally controlled) than citizens: "For example, I too have my own civic organization, which I do not promote anywhere, do nothing with it. It just exists, because I clearly understand - I'm its head..., the graters are perpetually tired, I simply make certain requests to the President's office, requests to the prosecutor's office in order to know the things for myself. Or, again, to try to help someone in obtaining, let's say, citizenship" (I3). Therefore, the main actors of the practice of political participation in Ukrainian society are not individuals, but legally registered civic organizations. Important and influential initiatives can not be realized only through civic participation; cooperation with the powerful authorities is necessary: "The most effective tool for achieving the goals in civic activity is through political activity. Civic activists find common interests with political representatives and try to bring their ideas together" (I2).

This kind of situation may point that the procedures of political participation' practice are still institutionalized in Ukrainian society. Greater activity in the political field of already institutionalized civic organizations than stochastic associations of individuals can evidence about the struggle between civil society and the political elite to expand and liberalize the rights of political participation. Thus, nowadays civic organizations are obligatory mediators for the implementation of the conventional political participation of individuals in Ukrainian society: "We created a civic organization. When I looked at the fact that a lot of civic organizations in general were created in our region. I belong to the largest - it's the Family Circle of Dead Heroes. It brings together parents, mothers, and children of those who died for Ukraine. And the second civic organization we created is called Ukrainian Ethnic Community and through it we realize many projects" (I9).

Such a civic organization is a social group that unites individuals with the same goals and value orientations in the political sphere. Members of such organizations can widely vary in occupations, education or income, but have a number of common political identities, a sense of the necessary future: "Well, our group on professional orientation is such a vinaigrette and very different, and then as we treat the world - is similar, because everyone is trying to focus more attention on some good actions and on a positive attitude towards life, put emphasis" (I7). The power of such an organization is determined by the present level of the social capital - the level of internal interpersonal trust and a network of influential friendly ties: "No, not subordinates. That's all on the horizontal level where the decision making should be. It is obligatory. That moves away from hierarchical system completely. Starting from the middle of yourselves» (I8); "I try to help people as much as possible. Thus, sometimes the help comes quite unexpectedly from the other side - you do not expect, but the help comes" (I10). A particularly important role in the life of civic organizations is played by Facebook. This platform can be used by civic organization as a space of accumulation of social capital and as a mobilization platform for its actions: "Who wanted-agreed. Somebody agreed, somebody did not agree" (I6).

During the interview it was discovered that the practice of political participation is actualising the lines of social division. Lines of social divisions through political participation are transformed into a sociocultural conflict: "Perhaps the main reason is... prejudice of Antimaidan that if Ukraine joins the EU then it will be Sodom and Gomorrah and that joining the EU means single-sex partnership, and I am for the single-sex partnership" (I8). Through 
political participation a deep identification with a certain social group (community) that represents and protects the identities of the individual takes place: "And then there was the Maidan, and I of course was on Kiev Maidan where I saw representatives of the scientific and creative intelligentsia. And even if somebody said that there gathered trashes, junkies indeed in December, November in Dnipro and Kyiv there were the best representatives of the Ukrainian' intelligentsia, and it was reasonably called the "Revolution of Dignity"'" (I9). In fact, the social group (community), with which the individual identifies himself, represents the side of the sociocultural conflict. The members of such groups established the cognitive schemes of division of the actors of the social space into "We-They-Others": "So I thought, watching there..., well, who we have now - "Donetsk's" they have 5-10 children. We "Patriots", who are smart people with a brain, have 1 child each. It turns out that the best of the nation will die, go to recession" (I4); "Thanks to Maidan I saw real Ukrainians. Not these opportunists, who can only adapt to certain political structures, but who see and know what they want to do" (I3).

The hidden purpose of the members of these groups (communities) is to win the sociocultural conflict by spreading their identities (values, cultural, ideological') among the whole society as a mandatory norms. The only possible way to do this is through political participation that can provide the political power to a social group: "I saw how people simply took actions with pleasure and they did not provide any financial benefit. That was what they had in their consciousness - it is necessary to do so, that's all. And I would like, maybe this is not a completely formed goal, everyone to understand that it is just necessary to do a good job" (I7). Thus, the political participation is particularly relevant for socially excluded groups whose sociocultural specifics of life are recognized as deviant, and the civil rights are limited: "Because when I began to talk about such things as sorting rubbish, then Conchita Wurst won Eurovision and it was a nightmare. Because boys, girls started talking about LGBT in a humiliating way. I had a short hairstyle and I..., the more I said that the normal gal this Conchita was, the more they said no, that it's wrong. And when I realized that this society is ready to eat any other person for its originality or variety, which does not fit the norm, and people are not ready to be open up to new prospects, they are not ready to take out the rubbish - plastic in one, iron in another - I realized that something needs to be changed" (I8).

Thus, according to our interviews, the political participation, at the individual level, always seems to be a pragmatic action. The political participation appears as a means for: improving quality of life conditions, elimination of deviant status, access to the procedures and resources of the political system, protection of one's own social position and identities: "You help, you do, but for your own pleasure. As I usually say: all people think only about themselves, nothing else should be" (I3). The success of the implementation of political participation depends on the capacity (resources and connections) of the social group (civic organization) which includes the individual. Purely individual initiatives will not have an effective impact on the structures of the political system: "Because if you live in a society of some kind of ghetto, in rude terms, then you will not have a good life. And if you help people to get a more decent salary, education, then they will get better, and your life will also get better. Something like that. Therefore, it is important to develop yourself and try to do something good and at least encourage others by your example. They poke to get on the right path. One person can not change everything, but when the majority, or at least a third, starts doing something, then we can speak about the result" (I5).

\section{Conclusions}

The purpose of this work was to explore the individual significance of political participation in modern Ukrainian society. The concept of political participation has a rich 
history of theoretical knowledge. Changing the paradigms of scientific knowledge in social sciences marked the problem of searching new methodological strategies for the empirical researches. Another problem is the limited universality of "democratic" theories for transformational societies. The problems is posed by the difficulties of predicting the influence of sociocultural factors on the functioning of democratic political procedures. The study of the real influence of such sociocultural factors requires the use of qualitative methods of analysis. Thus, the specificity of our work was to study the political participation as a social practice of individuals in a transformational society.

Thus, according to the results of the interviews, we have identified that: firstly, the practice of political participation is still institutionalizing in the structure of the Ukrainian political system. Therefore, only basic forms (voting in elections etc.) of political participation of the population are widespread (Udzhmadzhuridze, 2017). The implementation of more complex conventional forms of political participation is complicated by blockades from political elites. We can suggest that limiting the rights of political participation of citizens served as an influential factor of supporting the unconventional political participation of the population in 2013-2014 (Revolution of Dignity).

Secondly, the political participation has signs of social-psychological need of person: it helps to reduce the level of socio-political deprivation, obtain the social identities, include into the struggle for the definition of norms of social order. Therefore with the blocking and limiting political participation by political institutions, the protest forms of political participation are beginning to dominate; with partial blocking and limiting - civic participation of citizens is actualized; with the absence of restrictions - the conventional political participation is dominating, in the forms of initiative projects and requirements to the authorities (support and demands). In the contemporary Ukrainian society there is a latent conflict between civic organizations, representing the civil society, and political authorities for expanding the rights and opportunities of political participation.

Thirdly, the political participation actualises the lines of social divisions. Ukrainian society is permeated with a number of sociocultural differences that are related to the sociohistorical context of the formation of the Ukrainian state. The continuation of the limitation of access of communities and social groups to political participation will intensify the ideologization and extremization of the population, which can lead to a destructive sociocultural conflict. Instead, expanding the rights of political participation will bring the Ukrainian political system closer to a model of European consensus democracy.

The results of this study are not to be represented for the entire population of Ukraine, however it can enrich the empirical knowledge about the status of politically active citizens and the specificity of their political participation in the industrial and urbanize developed city of Ukraine. The heuristic achievements of this article are valuable for further researches of political participation in Ukraine and in other countries in the methodological and applicational aspects.

\section{References}

Aasland, A., \& Lyska, O. (2016). Local democracy in Ukrainian cities: civic participation and responsiveness of local authorities. Post-Soviet Affairs, 32(2), 152-175. doi:10.1080/1060586X.2015.1037072

Almond, G. A., \& Verba, S. (2015). The Civic Culture: Political Attitudes and Democracy in Five Nations. New Jersey: Princeton University Press.

Almond, G. A., Powell Jr., G. B., Dalton, R. J., \& Strom, K. (2007). Comparative Politics Today: A World View (9th ed.). New York: Longman.

Boltanski, L., \& Chiapello, E. (2007). The New Spirit of Capitalism. London: Verso. 
Boltanski, L., \& Thevenot, L. (2006). On Justification: Economies of Worth. New Jersey: Princeton University Press.

Bortnykov, V. (2007). Sociokuljturnyj vymir politychnoji uchasti. Politychnyj menedzhment [Sociocultural measurement of political participation]. Political management(5), 76-91.

Bourdieu, P. (1998). Practical Reason: On the Theory of Action. Redwood City: Stanford University Press.

Certeau, M. (2011). The Practice of Everyday Life. Oakland: University of California Press.

Chyseljnistj najavnogho naselennja Ukrajiny [The number of population of Ukraine on January 1, 2018]. (2018, January 1). Retrieved December 04, 2018, from State Statistics Service of Ukraine: http://www.ukrstat.gov.ua/druk/publicat/kat_u/2018/zb/06/zb_chnn2018pdf.pdf

Chyseljnistj naselennja (za ocinkoju) na 1 serpnja 2018 roku ta serednja chyseljnistj u sichnilypni 2018 roku [Population (estimated) as of August 1, 2018 and average number for January-July 2018]. (2018, August 1). Retrieved December 04, 2018, from State Statistics Service of Ukraine: http://www.ukrstat.gov.ua/operativ/operativ2018/ds/kn/kn_u/kn0718_u.html

Dahrendorf, R. (2007). The Modern Social Conflict: The Politics of Liberty. New Jersey: Transaction Publishers.

Diez-Medrano, J. (n.d.). Building the Tradrat and Survself factors. Retrieved December 04, 2018, from World Values Survey Association: http://www.worldvaluessurvey.org/WVSContents.jsp

Dokhody naselennja po reghionakh Ukrajiny [Population income by regions of Ukraine]. (2017). Retrieved December 04, 2018, from State Statistics Service of Ukraine: http://www.ukrstat.gov.ua/operativ/operativ2008/gdn/dvn_ric/dvn_ric_u/dn_reg2013_u. html

Giddens, A. (2009). Sociology (6th ed.). Cambridge: Polity Press.

Giddens, A. (2011). Runaway world : how globalization is reshaping our lives. London: Routledge.

Habermas, J. (2000). The Inclusion of the Other: Studies in Political Theory. Cambridge: The MIT Press.

Huntington, S. P. (2006). Political Order in Changing Societies. New Haven: Yale University Press.

Inglehart, R., \& Welzel, C. (2005). Modernization, Cultural Change, and Democracy: The Human Development Sequence. Cambridge: Cambridge University Press.

Kliuienko, E. (2005). Polytycheskoe uchastye: teoryja, metodologhyja y yzmerenye s prymenenyem metoda shkaloghrammyrovanyja po Ghuttmanu [Political Participation: Theory, Methodology, and Measurement Using the Guttman Scaling Method]. Sociology: theory, methods, marketing(4), 46-72.

Lipset, S. M. (1985). Political Man, the Social Bases of Politics. Baltimore: Johns Hopkins University.

Lundåsen, S. (2014). Civil Society and Political Participation: What Type of Political Participation is Influenced by Community Level Involvement in Civil Society? Swiss Political Science Review, 140-157. doi:10.1111/spsr.12140

Makarenko, B. (2014). Politychna uchastj jak politychna aktyvnistj osobystosti v transformacijnomu suspiljstvi [Political participation as the political activity of the individual in a transformational society]. Gileya, 90, 362-367.

Marchenko, A. (2016). Civic activities in Eastern Europe: links with democratic political culture. East European Politics, 32(1), 12-27. doi:10.1080/21599165.2015.1130698

Nacionaljnyj sklad naselennja Ukrajiny ta jogho movni oznaky [National composition of the population of Ukraine and its language features]. (2001). Retrieved December 04, 
2018, from State Statistics Service of Ukraine: http://2001.ukrcensus.gov.ua/d/nl_2001.rar

Olson, M. (1993). Dictatorship, Democracy, and Development. The American Political Science Review, 87(3), 567-576.

Opinions and views of Ukrainian people: December 2016 (KIIS Omnibus 2016/12). (2016). Retrieved December 04, 2018, from National Bank of Researches: http://ukraine.survey-archive.com/data\#user-research@showResearch=118402

Otnoshenye zhytelej Dnepropetrovskoj oblasty $k$ vneshnepolytycheskym, zemeljnblm $y$ drughym voprosam [Attitude of the inhabitants of the Dnipropetrovsk region to foreign policy, land and other issues]. (2015, December). Retrieved December 04, 2018, from Sociological Group «Rating»: http://ratinggroup.ua/files/ratinggroup/reg_files/rg_ec_ru_dnipropetrovsk_122012.pdf

Parsons, T. (1971). System of Modern Societies. Englewood Cliffs: Prentice-Hall.

Putnam, R. D., Leonardi, R., \& Nanetti, R. Y. (1994). Making Democracy Work: Civic Traditions in Modern Italy. New Jersey: Princeton University Press.

Relighijni vpodobannja naselennja Ukrajiny [Religious preferences of the population of Ukraine]. (2015, April 10). Retrieved December 04, 2018, from Sociological Group «Rating»:

http://ratinggroup.ua/research/ukraine/religioznye_predpochteniya_naseleniya_ukrainy. html

Reznik, O. (2016). From the Orange Revolution to the Revolution of Dignity Dynamics of the Protest Actions in Ukraine. East European Politics \& Societies, 30(4), 750-765. doi:10.1177/0888325416650255

Savelyev, Y. (2016). Decomposition of Value Change in European Societies in 1995-2008: Test of Modernization Model and Socialization Hypothesis. Sociológia, 48(3), 267-289.

Siryi, Y. (2016). The role of "deprivation" in the conceptualization of social tension in the Ukrainian society. Economics, Management and Sustainability, 1(1), 42-48. doi:10.14254/jems.2016.1-1.4

Smyth, R. (2018). Considering the Orange legacy: patterns of political participation in the Euromaidan Revolution. Post-Soviet Affairs, 34(5), 297-316. doi:10.1080/1060586X.2018.1505222

Torikai, M. (2018). Were All Ukrainians Orange? The Political Machine and the East-West Division in the 2004 Ukrainian Presidential Elections. Slavic Studies, 65, 1-38. Retrieved December 04, 2018, from http://src-h.slav.hokudai.ac.jp/publictn/slavicstudies/65/Torikai\%20Masatomo.pdf

Udzhmadzhuridze, H. (2017). Chynnyky nerivnosti politychnoji uchasti v suchasnomu Ukrajinsjkomu suspiljstvi: dosvid zastosuvannja binarnoji loghistychnoji reghresiji [Factors of Inequality of Political Participation in the Modern Ukrainian Society: the Experience of Applying of Binary Logistic Regression]. Bulletin of the V. N. Karazin KNU. Series "Sociological Researches of Modern Society: Methodology, Theory, Methods", 39, 167-174.

Wawrzonek, M. (2014). Ukraine in the "Gray Zone". Between the "Russkiy Mir" and Europe. East European Politics and Societies, 28(4), 758-780. doi:10.1177/0888325414543947

World Value Survey 1981-2014 Longitudinal Aggregate v.20150418, 2015. (2015). Retrieved December 04, 2018, from World Values Survey Association: www.worldvaluessurvey.org 


\section{APPENDIX 1}

\section{Guide of the interview:}

1. Tell us a little about yourself. What are you doing now, in which area are you working, perhaps you are implementing an important project?

2. What are you interested in at all. Perhaps you have any hobbies, a favourite thing?

3. Do you remember when you started to take an interest in it? Why did it start to fascinate you? Perhaps someone gave you an example?

4. Is there anything that you would like to add to your life - a certain goal, the achievement of which is associated with finding of the desired?

5. How can this goal be achieved?

6. In your opinion, do people usually achieve what they want in our country? Perhaps you can give a good example?

7. Let's talk about your experience of achieving the goal. Please tell about this experience. What was the situation there; who or what helped you in achieving the desired?

8. What did you feel when you achieved what you desired? What emotions prevailed; what did you think to do after achieving this goal?

9. Have you started to treat things in a different way; has your vision of the world, attitude to people changed?

10 . What did you learn about yourself personally after this experience?

11. How did this experience affect you in the future?

12. What could you advise those who were in such situation - in the sense of those who also need to achieve a certain goal?

13. Did you acquire any new hobbies, interests, activities, friends and acquaintances after these events?

14. Summary of the interview (informant before and after the events). 


\section{APPENDIX 2}

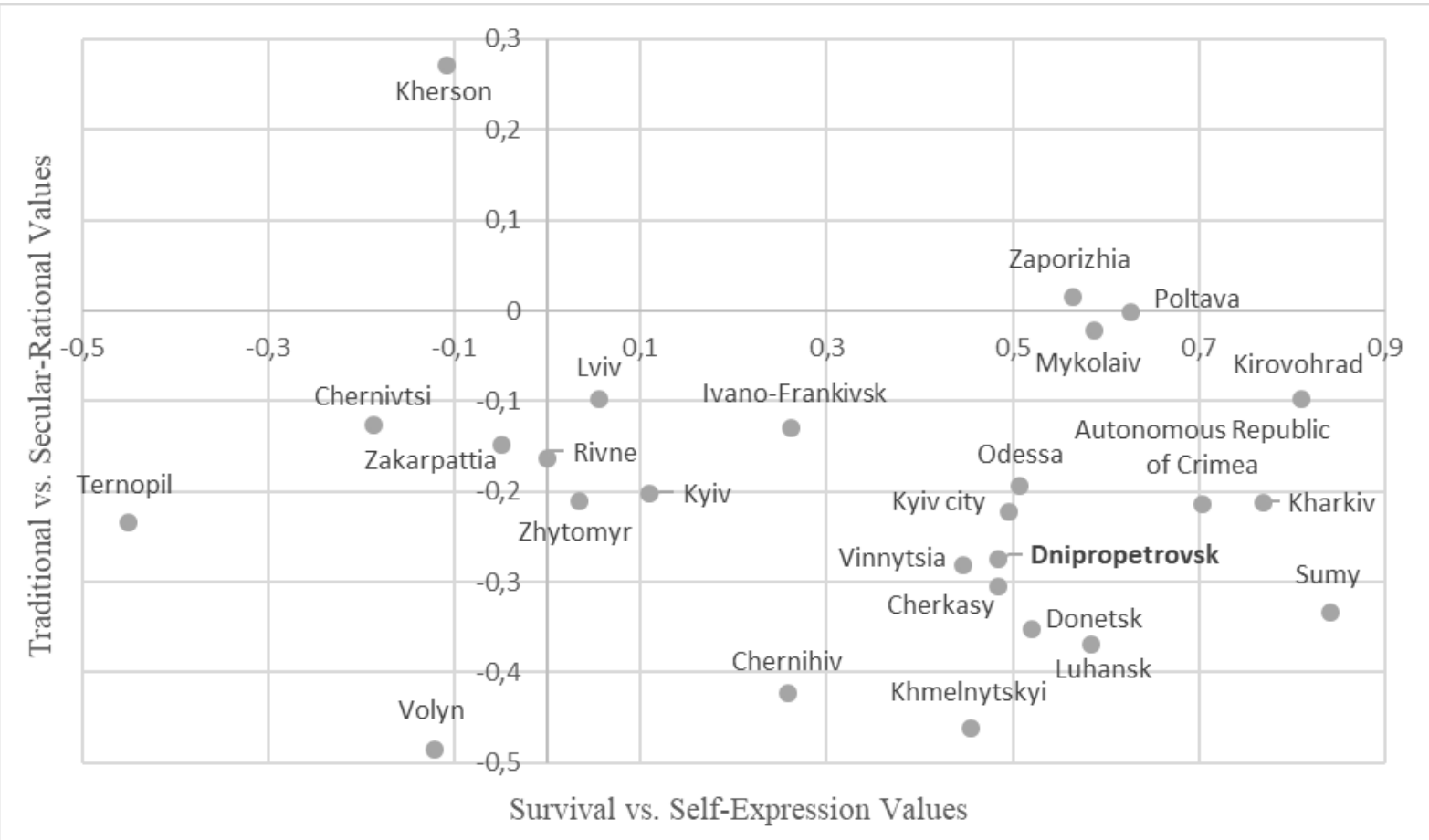

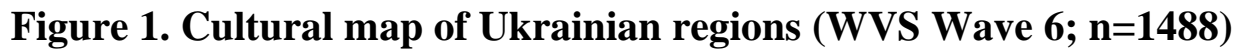

Source: World Values Survey Longitudinal data (WVS, 2015) 